Tuberculosis and Respiratory Disease

결핵 및 호흡기질환, Vol. 39, No. 4, August, 1992

$\square$ 증 례 $\square$

\title{
Nocardiosis 1예
}

경희대학교 의 과대학 내과학교실, 임 상병리학교실*

김정회・윤기헌 - 유지홍·강홍모・서진태*

$=$ Abstract $=$

\author{
A Case of Nocardiosis \\ Jeong Hee Kim, M.D., Ki Heon Yoon, M.D., Jee Hong Yoo, M.D. \\ Hong Mo Kang, M.D. and Jin Tae Suh, M.D* \\ Department of Internal Medicine and Clinical Pathology* College of Medicine, \\ Kyung Hee University, Seoul, Korea
}

\begin{abstract}
Nocardiosis is an acute, subacute or chronic infection, which usually introduced through the respiratory tract resulting pneumonia, and may develop a disseminated infection, especially subcutaneous abscess and/or CNS infection. It is usually affects the immunocompromized host and may be fatal unless early diagnosis and adequate treatment are performed.

There have been only several case reports of nocardial infection in Korea. Nocardiosis is so unfamiliar to many physicians that may be misdiagnosed as pneumonia, tuberculosis, or neoplasm.

We have experienced a case of nocardiosis from a patient who had been treated as pneumonia and tuberculosis at first. The 57-year-old male patient had fever, chill, dyspnea and blood tinged purulent sputum for 20 days. Under the impression of bacterial pneumonia, broad spectrum antibiotics were administered for more than 3 weeks without clinical improvement. Although antituberculous drugs began to be administered after acid fast bacilli were found in bronchial aspirate by bronchos. copy, the nocardial infection was suspected due to no clinical response toward antituberculous therapy and the occurrence of multiple subcutaneous abscesses on scalp. The diagnosis was made by modified Ziehl-Neelson stain and culture of the sputum and pus. Nocardia asteroides was identified. After 25 days of trimethoprim-sulfamethoxazole treatment, the patient was much improved and discharged.
\end{abstract}

Key Words: Nocardiosis, nocardia asteroides

서

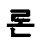

Nocardiosis는 대부분이 폐의 감염으로 시작되어 뇌 또는 피하조직으로 혈행성 전이를 일으킬 수 있는 급성, 아급성 또는 만성 세균성 감염이다. 대개 면역기전에 이 상이 있는 사람에서 발생하며, 이 경우에는 급성 경과를 밟을 수 있으므로 조기에 진단하여 적절한 치료롤 하지 않으면 사망할 수도 있다.
1974년 이전까지는 전세계적으로 보고가 드물었으나 근래에 와서 면역억제제의 광범위한 사용과 임상가들의 이 진환에 대한 인식의 증가로 미국에서만 연간 $500 \sim 1000$ 명의 새로운 환자의 발생이 보고될 정도로 ${ }^{7)}$ 빈도가 중가하고 있는 추세이다. 그러나 국내에서는 1974년 고등2)이 Nocardia 균주의 첫 분리 사례를 보고 한 이래 임상보고가 희귀하여 다수의 임상가에게 익숙치 못한 질환이다.

저자들은 폐렴의 중세를 보이고 결핵이 의심되었던 환 
자의 객담과 두피 농양에서 Nocardia asteroides가 분리 동정된 1 예를 경험하였기에 이를 문헌고찰과 함께 보고 하는 바이다.

\section{증 례}

환 자: 박 $\bigcirc$ 준, 남자, 57 세.

주 소 : 호흡곤란, 화농성 객담.

현병력 : 환자는 10 년전에 시멘트 운반화물차를 3 년간 운전했던 경력이 있었으며, 3 년전 호흡곤란이 있어 개인 병원에서 촬영한 흥부 $\mathrm{X}$ 선 소견상 진폐증이 의심되었으 나 자세한 검사나 치료를 받지 않고 지내오던중, 20 일전 부터 고열, 오한과 함께 호흡곤란, 혈액이 섞인 화농성 객담, 20 일간 $10 \mathrm{~kg}$ 의 체중 감소가 있어서 내원하였다.

과거력 및 가족력 : 특이사항 없음.

개인력 : 직업-운전사.

음주-10년간 매일 소주 1 병.

홉연-30년간 매일 담배 1 갑.

이학적 소견 : 내원시 혈압 $140 / 90 \mathrm{mmHg}$, 맥박수 123 회/분, 호홉수 30 회/분, 체온 $38^{\circ} \mathrm{C}$ 였으며 의식은 명 료하였고 급성 병색의 소견을 보였다. 피부에 종창이나 결절은 없었고, 경부 강직이나 임파절 종대도 없었으며, 황달이나 빈혈의 소견은 없었다. 청진상 양쪽 전폐야에 서 수포음이 청진되었고, 심음은 빈맥의 소견은 있었지 만 잡음은 없었다. 복부는 이완되어 있었고, 간비장 비 대의 소견은 없었다. 신경학적인 이상소견도 없었다.

검사실 소견 : 일반 혈액 검사상 백혈구 $23,000 / \mathrm{mm}^{3}$ (중성구 $80 \%$, 임파구 $16 \%$, 단핵구 $4 \%$ ), 적혈구 429 만 $/ \mathrm{mm}^{3}$, 혈색소 $13.9 \mathrm{~g} / \mathrm{dl}$, 혈소판 32 만 $/ \mathrm{mm}^{3}$ 이었고, 일반 소변검사와 대변검사는 정상소견이었다. 혈액 화 학적 검사상 총단백 $6.3 \mathrm{gm} / \mathrm{dl}$, 알부민 $2.4 \mathrm{gm} / \mathrm{dl}$ 로 저 알부민혈증을 보였고 총콜레스테롤 $84 \mathrm{mg} / \mathrm{dl}$ 로 역시 저 하되어 있었다.

$\mathrm{SGOT} / \mathrm{SGPT}$ 는 39/29 IU/L로 정상범위였고, alkaline phosphatase가 $155 \mathrm{IU} / \mathrm{L}$ 로 약간 증가되어 있었 다. 홍부 X선 촬영 결과 좌측 폐하엽의 대부분을 차지하 는 심한 염증성 침윤이 관찰되어 폐렴이나 폐농양이 의 심되었다(Fig. 1). 제 20병일째 실시한 훙부전산화단층 촬영상 좌측 폐하엽의 염중성 침윤은 다양한 크기의 공 동으로 이루어져 있어 건락성 폐렴 (caseous pneumonia)을 의심케 하였다(Fig. 2).

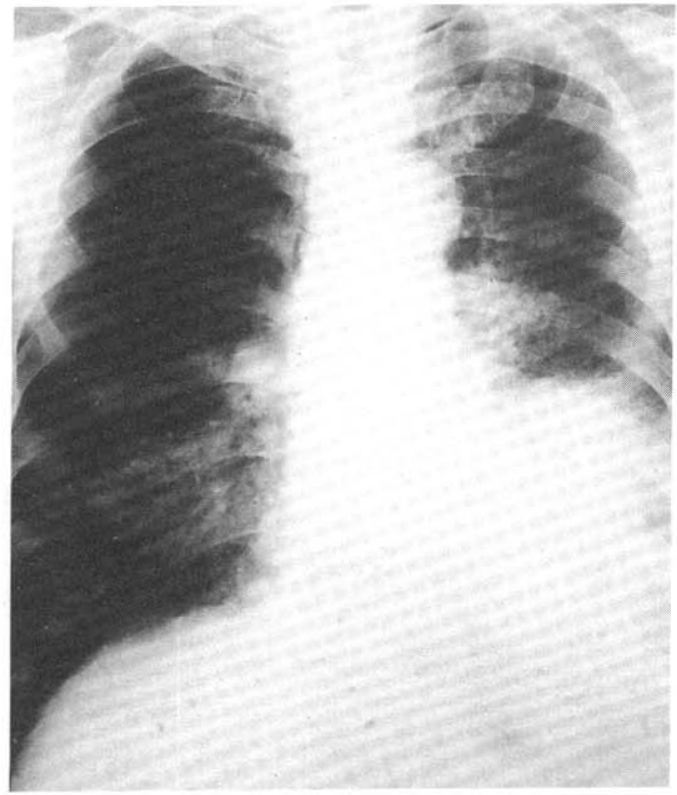

Fig. 1. Film of the chest obtained at admission reveal patchy infiltrations on left lower lung field.

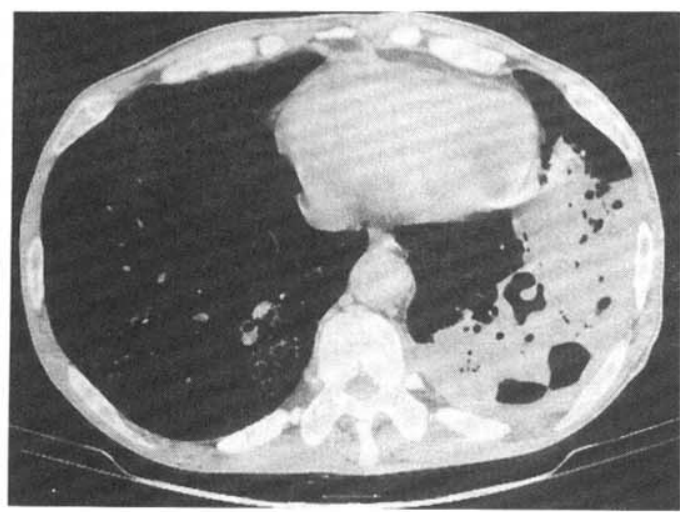

Fig. 2. Chest CT taken 13 days after admission shows consolidation of left lower lobe with multiple, variable sized cavities.

임상 경과 : 입원 당일부터 고열과 화농성 객담, 훙부 $\mathrm{X}$ 선상 폐렴의 소견이 있어 광범위 항생제(penicillin과 tobramycin)투여와 함께 결핵균 및 일반 세균에 대한 객담 도말 및 배양검사를 시행하였으나 모두 음성이었 다. 항생제의 투여에도 환자의 증상 및 추적 시행한 홍 부 X선 소견의 변화가 없어서 제 6병일에 항생제를 cefazolin, amikacin, clindamycin으로 바꾸었으며, 
제 17병일부터는 cefazolin을 piperacillin으로 대체하 였으나 호전되지 않았다. 제 13 병일에 기관지내시경을 시행하였는데 기관지내에 비정상적인 종괴는 관찰되지 않았고 화농성 분비물이 다량 흡입되었다. 흡입한 객담 의 도말검사에서도 $\mathrm{AFB}$ 음성이었고 배양검사에서도 병 원체가 발견되지 않았다. 그러나 제 23병일에 다시 시행 한 기관지 내시경검사시 홉입한 객담의 도말검사상 $\mathrm{AFB}$ 양성으로 밝혀져 결핵으로 진단하고 제 25병일부 터 항생제 투여를 중단하고 항결핵 약제(Isoniazid, Rifampicin, Ethambuthol, Pyrazinamide)를 투여하 기 시작하였다. 그러나 12 차례의 객담도말검사중 단 한

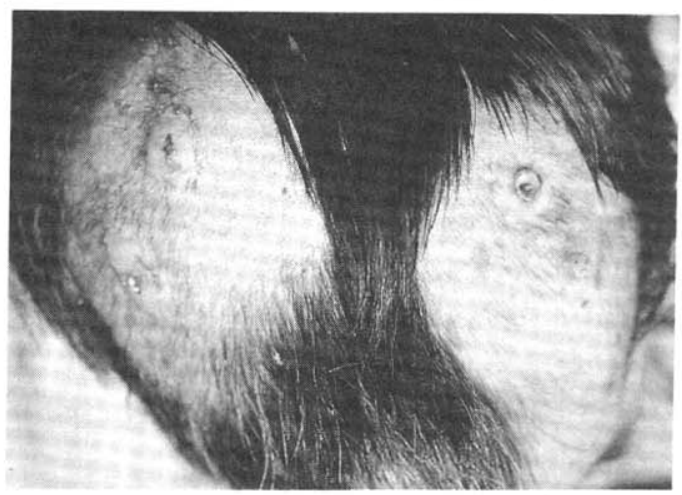

Fig. 3. Multiple abscesses were developed on scalp, at the 20 days after admission.
번만 $\mathrm{AFB}$ 양성으로 나온 점, 제 20 병일부터 환자의 두 피에 발생된 농양(Fig. 3)과의 연관성, 항생제 및 항결 핵제 투여에도 호전이 없는 점을 고려하여 임상적으로 nocardiosis를 의심하고 객담과 두피농양에서 채취한 검체를 다시 그람염색하여 그람양성의 균사성의 간균을 관찰하였으며(Fig. 4), modified Ziehl-Neelson염색에 서 사상형으로 분지되는 약 항산성의 병원체를 발견하였 다(Fig. 5).

Sabouraud's dextrose agar 와 Muller-Hilton 배 지 에 의한 배양결과 Nocardia의 성장이 있었으며 동정결 과 Nocardia asteroides로 규명되어 제 31병일째부터 Trimethoprim-sulfamethoxazole (septrim)의 투여를 시작하였다. Septrim투여후 1주일째부터 고열이 사라 지고 증상의 호전이 보였으며 제 53병일 (setrim투여 23 일째)에 홍부 X선소견(Fig. 6)도 현격한 호전을 보여 외 래에서 추적관리하기로 하고 퇴원하였다.

\section{고 안}

Nocardia는 1888년 Nocard가 소의 농액에서 최초로 분리하여 명명하였으며, 사람에서는 1890년 Eppinger 에 의해 폐질환 및 뇌농 양의 소견을 보이는 pseudotuberculosis syndrome환자의 뇌농양 조직에서 배양하여 처음 보고되었달).

초기에는 진균학 분야에서 취급되었으나, 현재는 기

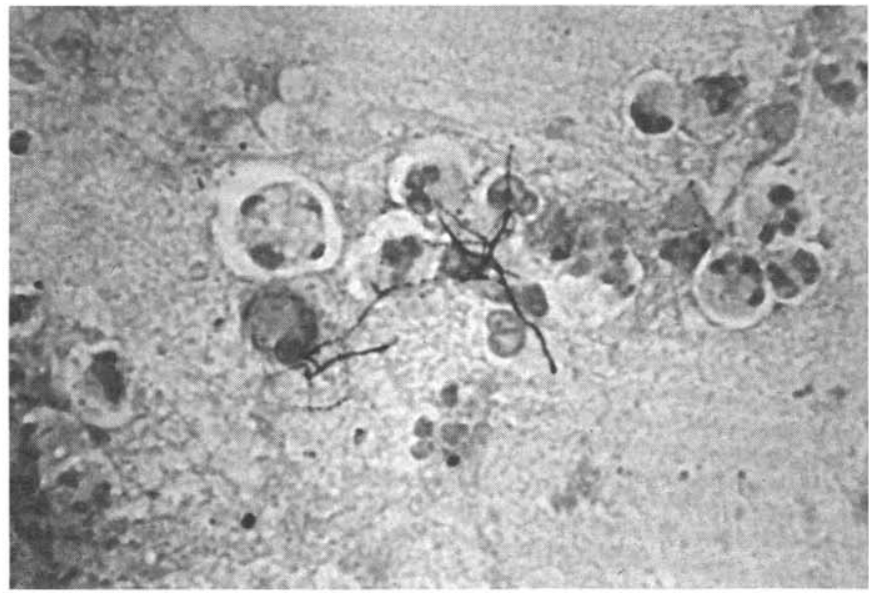

Fig. 4. Gram-staining of pus $(\times 1000)$ shows branching hyphae of $G(+)$ bacilli. 


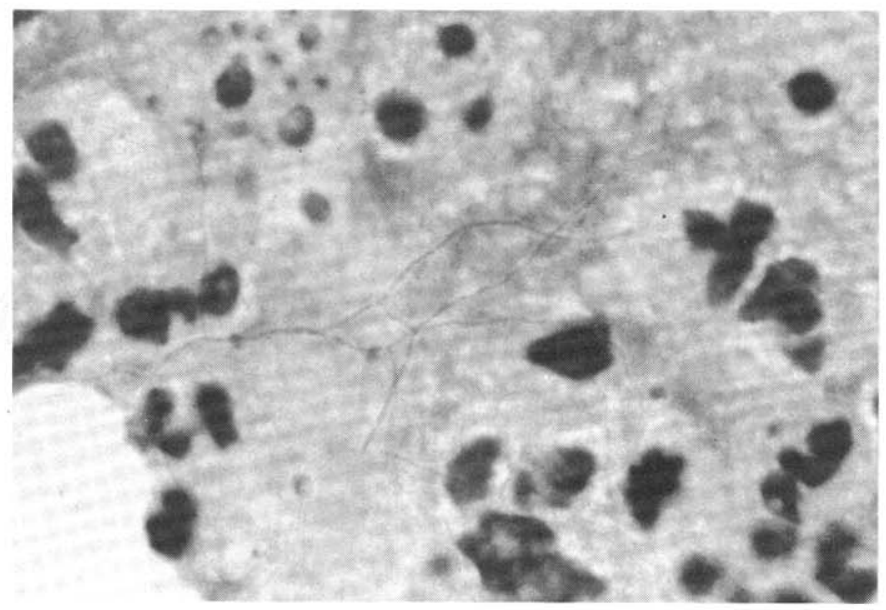

Fig. 5. Modified Ziehl-Neelson staing of sputum $(\times 1000)$ shows weak acid-fast bacilli.

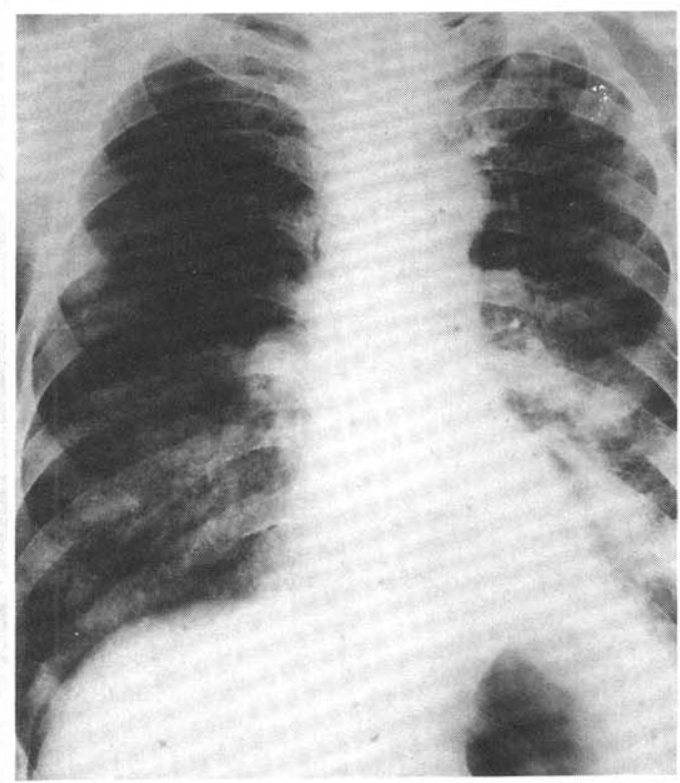

Fig. 6. Left lower lobe infiltrates were improved after 25 days of trimethoprim-sulfamethoxazole treatment.

질의 직경이 $1 \mathrm{micron}$ 이하, PAS(Periodic Acid Schiff)염색에 음성, sterol free인 세포막, sulfonamide등의 항진균성 작용이 없는 항생제에 대한 감수성 등의 특성으로 인하여 진균양 세균(fungus like bacteria)으로 알려져 있다 ${ }^{2,3,9}$.
Nocardia 의 분류학적 위치는 Actinomycetes 목 (order)중 Nocardiaceae 과 (family)에 속하며 이 Nocardiaceae는 다시 Nocardia와 Actinomadura의 속 (Genus)으로 나뉘고 Nocardia속에 속하는 종으로는 asteroides, brasiliensis, carviae가 있으며 이중에 주로 인체에 감염을 일으키고 독성이 많은 것이 N. asteroi$d e s$ 로 폐렴과 전신적 파급을 일으킨다9).

Nocardia는 호기성의 그람 양성균으로 약 항산성을 가지며 Actinomyces와 모양이 비슷하면서 혐기성이 아 니어서 호기성 Actinomycosis로 불리우기도 하였었다. Nocardia는 호기성이고 필요한 영양분도 적어서 일반적 이고 비선택적인 배지에서 잘 자라며, 진균 배지에서는 진균분리를 위하여 포함된 항생제에 의하여 배양이 억제 되어 자라지 않는다. Sabouraud 한천배지나 혈액한천 배지에서는 잘 자란다. 그러나 객담등의 혼합된 검체의 배양에서는 특징적인 집락을 보이는데 2 4주의 시일을 요한다. 따라서 2 일간만 실시하는 일반적인 방법으로는 발견하지 못하는 수가 많다. 항산성은 Mycobacterium tuberculosis보다 약하여 acid-alcohol 용액에 탈색되므 로 $1 \%$ sulfuric acid를 쓰는 modified Ziehl-Neelson 염색법을 사용하면 관찰이 가능하다. Nocardia는 도말 검사와 배양검사에서 동시에 발견할 수 있는 경우가 $1 / 3$ 정도밖에 되지 않아 반복적인 검사가 필요하다.

Nocardia의 감염은 주로 호흡기를 통해 이루어지며, 간혹 외상부위로 침입하여 피부 또는 각막등에 감염을 
일으키거나, 충수나 치흔둥에 감염을 일으키기도 한다. 환자로부터의 직접 전염은 없다고 알려져 있닿.

Nocardiosis는 주로 $(85 \%)$ 면역결핍환자에서 기회감 염으로서 발생하며 주된 기저질환으로 임파망상성신생 물, 폐포단백증, 천포창. 루프스, 천식, 사구체신염, Whipple씨병, Good-Pasture 중후군, 혈놘염, 쿠싱씨 병, 간경변증, 혈전전색증, 케양성 대장염, 기관지확장 증, 결핵, 탄분중 (anthrasilicosis), 유육종중, Paget씨 병둥이 있고 부신피질호르몬 장기복용자, 장기이식환 자, 만성알콜중녹중 환자에서도 발생할 수 있으며 최근 에는 AIDS환자에서의 감염이 중가하고 있다. 나머지 $15 \%$ 는 선행질환이 없이도 발생이 가능하다2,8).

역학적으로 볼때 외국의 경우 그 보고가 점점 늘고 있 어 미국에서는 1976년 한해에 500 1000명의 새로운 이 환자가 생긴다고 보고되었닥. 국내에서는 1974년 고 등1)이 결핵 환자들의 객담에서 Nocardia의 균주를 분리 한 보고가 있었고, 1975년 석등4)이 급성 임파구성 백혈 병 환자의 피부농양에서 $N$. brasiliensis롤 분리하였으 며, 1979년 안둥기에 의한 N. asteroides 농양 2예와 1987 년 김등 2 에 의한 피부 병변을 동반한 전신파종형 1 예, 1989년 김둥6)에 의한 Nocardiosis 2예, 1990년 라 등 ${ }^{3)}$ 에 의한 계속적 복막투석 환자에서 발생한 Nocardia 복막염 1예의 보고와 같이 몇몇 증례보고만 있는 정도로 드물다.

성별 발생분포를 보면 Muiray ${ }^{10}$ 둥은 남자환자가 $70 \%$ 를 차지한다고 보고하였으며, 다른 보고들에서도 남자 에서 2배정도 빈도가 높다고 하였다 ${ }^{7,12}$. 연령별 분포는 생후 4개월부터 그 보고가 있으남i) 대부분이 21 50세 사이에 발생된다고 보고하였다10). 가장 혼한 임상양상 은 폐렴으로, 서서히 진행하는 기침과 발열, 그리고 화 농성 또는 점액성 객담이 그 초기 중세이며 객담은 녹색 일 수도 있고 혈액이 섞인 혈담일 수도 있다. 그 외의 비 특이적인 중상으로는 식욕부진, 체중감소, 훙막염성 흥 통(pleuritic chest pain) 등이 있을 수 있다. 홍부 X선 소견상 기관지 폐렴에서 대엽성 폐렴으로 진행하여, 공 동 형성이나 늑막 침범도 혼하다. $25 \%$ 이상에서 농홍이 발생되며, 석회화나 육아형성은 드물다. 파종성 감염이 $50 \%$ 에서 발생하는데 주로 피하농양을 형성하거나 중추 신경을 침법하여 뇌농양, 뇌막염, 뇌실염등을 일으키 며, 그 외에 신장등의 다른 장기에도 전이병소가 생길 수 있다. Nocardia 폐렴은 경우에 따라서 결핵이나 신생
물, 또는 폐농양으로 오인되기도 한다. Nocardiosis는 완화와 악화가 반복되는 것이 특징이며 고위헙 환자군 (high risk group)에서 연부조직 종창이나 농양, 중추 신경계 중상의 발현, 재발성 결막염, 만성 혹은 아급성 폐렬이 나타날 때 의심하여야 한다.

진단은 상기의 특징적인 숭상 및 중후와 아울러 농양 이나 조직 및 분비물에서 Nocardia균을 발견하는 것 이 외에, hemagglutination 및 precipitating antibody에 의한 진단방법이 동물 실협에서 입중되었으며, 보체고 정항체 검사(complement fixation test)는 민감도는 높지 만 leprosy, tuberculosis, actinomycosis 등 에 서 위양성 반응이 나타날 수 있는 것으로 알려져 있다. 최 근에 55 kilodalton의 반정제(semipurified) 된 항원을 사용한 western blot 분석이나 EIA (enzyme immunoassay)로 Nocardia균울 진단했을때 민감도가 높고 다른 균종과의 교차반웅이 없다는 보고가 있어 고무적이 다 12 14). Nocardiosis는 대부분 만성 경과를 취하고 배 양검사에서도 균주가 서서히 자라기 때문에 특별한 관심 을 가지지 않으면 놓치기 쉬워 조기진단이 어려우며 특 히 유사한 홍부 X선 소견과 항산성을 가지는 톡징으로 인하여 Mycobacterium 이나 Actinomycetes에 의한 폐 렴과 폐농양과의 감별에 유의해야 한다. 본 예에서도 폐 농양 및 결핵으로 오인되어 입원후 1 달이 지나서야 균주 의 분리가 이루어졌음을 볼 때 진단의 어려움을 실감할 수 있다. 그러므로 임상가의 이 질환에 대한 인식과 균 도말검사 및 배양검사상 주의깊은 관찰이 필요하겠다.

Nocardiosis의 치료는 항균제 요법과 수술적 처치로 이루어지는데 항균제로는 1944년 sulfonamide의 효과 가 중명된 이래 치료의 1 차 선택제로 사용되어 왔으며, 최근에는 trimethoprim-sulfamethoxazole이 1차 선택 제로 사용되고 있다 ${ }^{16}$. 대체 약제로는 amoxicillinclavulanic acid가 있으며, erythromycin-ampicillin, sulfonamide-ampicillin, ampicillin-cloxacillin 등 의 상숭작용이 보고되었다. trimethoprim-sulfamethoxazole과 병용시 in vivo 및 in vitro에서 호과가 입증 된 제 제로 imipenem, amikacin, ampicillin 등이 있 다 ${ }^{17}$. 약의 용량은 sulfonamide제제의 경우 정상 신기 능의 성인에서는 병의 경중에 따라 1일 6 12 g을 4 6 번에 나누어 투여하며, 혈중농도는 $100 \sim 150 \mathrm{~g} / \mathrm{ml}$ 를 유 지하는 것이 좋다. 치료 기간은 6 개월에서 12 개월간 사 용해야 한다는 보고가 있당․ 수술적 처치로 외과적 절 
제 및 배농이 세균성 농양에서처럼 치료에 큰 도움이 되 며, 중추신경의 농양이 계속 커지거나 항생제요법에 흐 과가 없을 때 시행하는 것이 좋다. 기존질환에 대하여 면역억제제를 사용해야 하는 경우에 적절한 항균제 요법 과 병용하여도 치료에 큰 지강은 없다고 한다.

예후에 있어서 사망울은 sulfonamide제제의 도입전 에는 $75 \%$ 로 매우 높았으나 현재는 전체 사망율이 $50 \%$ 에 이른다고 하며9) 기존질 환이 없고 호흡기에 국한된 경 우에 사망율은 $15 \%$ 정도라고 보고되었당. Persant 등 ${ }^{15)}$ 에 의하면 급성 감염의 형태로 온 후 중상이 3 주 정 도 지속되는 경우, 부신피질호르몬제나 항암제 사용시, 쿠싱씨병이 기존질환으로 있는 경우 그리고 전신적 파종 이 있는 경우에 사망율이 높다고 하였고, 톡히 부신피질 호르몬제의 사용여부가 사망율에 큰 영향을 미친다고 하 였다. 사망원인은 패혈중, 뇌농양, 폐렴, 기존질환의 악 화등이라고 하였다.

\section{요 약}

저자들은 57세 남자환자에서 전형적인 Nocardiosis 의 임상상을 보이고 객담 및 피부 농양에서 Nocardia asteroides가 분리 동정된 1예를 경협하였기에 이를 문헌 고찰과 핚께 보고하는 바이다.

\section{REFERENCES}

1) 고준명, 김준걸, 이정우, 이일선, 이원명 : 결핵병동 입원 환자 객담에서 분리한 Nocardia속의 동정과 약제 감수성에 관한 실협. 최신의학 17:1257, 1974

2) 김종진, 정진민, 신완식, 강문원, 한경자, 전성주 : Nocardia asteroides 1예 보고. 감염 19:57, 1987

3) 라동집, 최창현, 우준희, 박민선, 한동철, 이상구, 이 회발 : 계속적 외래 복막투석 환자에서 발생한 Nocardia 북막염 1에. 감염 22:97, 1990

4) 석종영, 이재철, 이송훈: Nocardia brasiliensis의 분 리 및 생물학적 성상에 관하여. 대한미쌩물학희지 10: 25,1975
5) 안용모, 정윤석, 이삼염, 김병수, 이회수: Nocardia asteroides 농양 2예. 대한병리 학회지 10:25, 1975

6) 김성 민, 김양수, 배현주, 신형식, 백경란, 최강원 : Nocardiosis 2예. 감염 1:217, 1989

7) Beaman BL, Burnside J, Edwards B, Causey W: Nocardial infections in the United States, 19721974. J Inf Dis 134:286, 1976

8) Lerner PI: Nocardia species. In Mandell GL, Doug. las RG Jr., Bennet JE (Ed) Principles and practice of infectious disease, 2nd ed., p 1423, New York, A Wiley medical publication, 1985

9) Hoeprich PD: Infectious disease, 3rd ed., p 419, Philadelphia, Harper $\varepsilon$ Row, A Wiley medical publication, 1985

10) Muiray JF, Finegold SM, Froman S, Will DW: The changing spectrum of nocardiosis: $A$ review and presentation of nine cases. Am Rev Resp Dis 83:315, 1961

11) Lampe RM, Bake CJ, Septimus EJ, Wallace RJ: Cervicofacial nocardiosis in children. J Pediatrics 99:593, 1981

12) Stevens DA: Clinical and clinical laboratory aspects of nocardial infection. J Hygiene (Lond) 91:377, 1983

13) Sugar AM, Schoolink GK, Stevens DA: Antibody response in human nocardiosis identification of two immunodominant culture-filtrate antigens derived from Nocardia asteroides. J Infect Dis 151:895, 1985

14) Angeles AM, Surgar AM: Rapid diagnosis of nocardiosis with an enzyme immunoassay. J Infec Dis 155: 292, 1987

15) Persant CA, Wiemik PH, Serpick AA: Factors affecting survival in nocardiosis. Am Rev Resp Dis 108:1444, 1973

16) Smego RA, Mocller MB, Gallis HA: Trimethoprimsulfamethoxazole therapy for Nocardia infections. Arch Intern Med 143:711, 1983

17) Gobert ME, Aulicino TM, Dubouchet L, Silverman GE: Therapy of experimental cerebral nocardiosis with Imipenem, Amikacin, Trimethoprimsulfamethoxazole, and Minocycline. Antimicrob Agents Chemother 30:270, 1986 